\title{
Computational model of medial temporal lobe epilepsy
}

\author{
Sora Ahn', Sangbeom Jun', Hyang Woon Lee², Seungjun Lee ${ }^{1 *}$ \\ From 24th Annual Computational Neuroscience Meeting: CNS*2015 \\ Prague, Czech Republic. 18-23 July 2015
}

Temporal lobe epilepsy represents a high proportion of whole epilepsy patients. Medial temporal lobe epilepsy (MTLE) is generated from internal structures like hippocampus, and patients with MTLE are poorly controlled by antiepileptic drugs [1]. Recently, deep brain stimulation (DBS) that is to control seizure activity by stimulating epileptic zone is receiving attention as a new treatment of epilepsy. However, the exact mechanisms are still unclear and the current method is being developed relying on clinical experiences. Consequently, researches for etiology of disease along with seizure suppress mechanisms by electrical stimulation are very significant. These studies would be best progressed with complementary cooperation between in-vitro and in-vivo experiments, and computer simulations using a computational model.

In this paper, we propose a hippocampal network model which portrays seizure-like events (SLEs) recorded in in-vitro experiments. The model is composed of excitatory and inhibitory neurons interconnected following the wellknown synaptic pathway to form a small world network [2]. Each neuron is descripted by Izhikevich's model [3] and synaptic current is calculated based on conductance of a receptor. Short-term and long-term plasticity are also applied to every synapse [4]. SLEs induced by 4-AP are divided into three regions according to time-frequency features. The first region is transition to ictal region by excitatory GABAergic drive [5], the second region is tonic firing region by synchronization due to recurrent excitation between principle neurons [6], and the last region is clonic bursting and termination region by GABA-mediated inhibitory mechanisms [1]. Proposed model faithfully reproduces these phenomena by controlling synaptic input gain.

The effectiveness of the model is confirmed by comparing the simulation results with experimental data
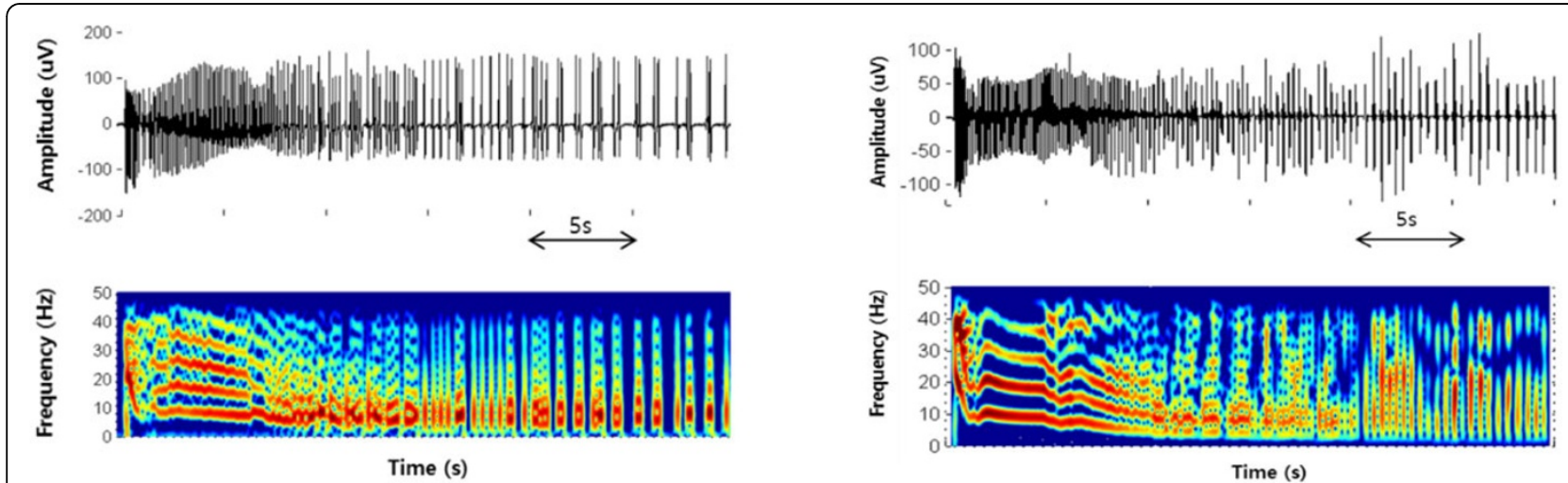

Figure 1 Recording data (left) and simulation result (right) of seizure-like events in entorhinal cortex

\footnotetext{
* Correspondence: slee@ewha.ac.kr

${ }^{1}$ Department of Electronics Engineering, Ewha Womans University, Seoul,

120-750, Korea

Full list of author information is available at the end of the article
}

(c) 2015 Ahn et al. This is an Open Access article distributed under the terms of the Creative Commons Attribution License (http:// creativecommons.org/licenses/by/4.0), which permits unrestricted use, distribution, and reproduction in any medium, provided the original work is properly cited. The Creative Commons Public Domain Dedication waiver (http://creativecommons.org/publicdomain/ zero/1.0/) applies to the data made available in this article, unless otherwise stated. 
which were recorded in rat hippocampal slice in 4-AP bath application using micro-electrode array (MEA). Below Figure 1 are time domain signals generated from computer model and recorded in in-vitro measurement, respectively.

\section{Authors' details}

'Department of Electronics Engineering, Ewha Womans University, Seoul, 120-750, Korea. ${ }^{2}$ Department of Neurology, Ewha Womans University, Seoul, 120-750, Korea.

Published: 18 December 2015

\section{References}

1. Avoli M, D'Antuono M, Louvel J, Köhling R, Biagini G, Pumain R,

D'Arcangelo G, Tancredi V: Network and pharmacological mechanisms leading to epileptiform synchronization in the limbic system in vitro. Prog Neurobiol 2002, 68:167-207.

2. Netoff Tl, Clewley R, Arno S, Keck T, White JA: Epilepsy in small-world networks. J Neurosci 2004, 24(37):8075-8083.

3. Izhikevich EM: Simple model of spiking neurons. IEEE Trans Neural Netw 2003, 14(6):1569-1572.

4. Izhikevich EM, Gally JA, Edelman GM: Spike-timing dynamics of neuronal groups. Cereb Cortex 2004, 14(8):933-944.

5. Staley KJ, Soldo BL, Proctor WR: Ionic mechanisms of neuronal excitation by inhibitory GABAA receptors. Science 1995, 269:977-981.

6. Ziburkus J, Cressman JR, Barreto E, Schiff SJ: Interneuron and pyramidal cell interplay during in vitro seizure-like events. J Neurophysiol 2006, 95:3948-3954.

\section{Submit your next manuscript to BioMed Central} and take full advantage of:

- Convenient online submission

- Thorough peer review

- No space constraints or color figure charges

- Immediate publication on acceptance

- Inclusion in PubMed, CAS, Scopus and Google Scholar

- Research which is freely available for redistribution

Submit your manuscript at www.biomedcentral.com/submit 